\title{
OPTIMASI PERSEDIAAN SPARE PART UNTUK MENINGKATKAN TOTAL PENJUALAN DENGAN MENGGUNAKAN SIMULASI MONTE CARLO (STUDI KASUS DI PT. ZXC)
}

\author{
Iphov Kumala ${ }^{1}$, I Wayan Sukania ${ }^{2}$ dan Santo Christianto ${ }^{2}$ \\ ${ }^{1}$ Program Studi Teknik Industri, Universitas Esa Unggul \\ ${ }^{2}$ Program Studi Teknik Industri, Universitas Tarumanagara \\ e-mail: santo545120007@yahoo.com
}

\begin{abstract}
ABSTRAK
PT. ZXC merupakan perusahaan yang bergerak di bidang sales (showroom) dan After Sales Service termasuk penjualan spare part (Vehicle Service Part). Pada bidang spare part terdapat berbagai kategori yang ada untuk tiap spare parts berdasarkan demand atau pergerakannya, yaitu fast moving, slow moving, non moving (dead stock), dan new model. Sistem pemesanan yang dilakukan untuk memenuhi persediaan tidak berdasarkan pada jumlah permintaan yang akan datang. Penelitian dilakukan untuk dapat membantu perusahaan agar dapat meningkatkan total penjualan dengan memberikan usulan perbaikan pada pemesanan spare parts pada kategori fast moving dengan menggunakan simulasi Monte Carlo. Penelitian ini juga diharapkan dapat membantu perusahaan untuk dapat melakukan perencanaan dan pengendalian terhadap permintaan konsumen dengan memperhatikan reorder point dan safety stock yang dihasilkan dari simulasi Monte Carlo. Pada penelitian ini parts yang akan diteliti, yaitu Air Cleaner, Oil Filter, dan Spark Plug karena part tersebut merupakan part fast moving tertinggi. Dalam penelitian ini, apabila menggunakan simulasi monte carlo terjadi peningkatan total penjualan yang dilihat berdasarkan keuntungan tiap bulannya. Pada tahun 2013 hingga Juni 2015, peningkatan tertinggi sebesar 2,622\% dan peningkatan terendah sebesar 0,117\%.
\end{abstract}

Kata Kunci: Spare Part, Sistem Pemesanan, Simulasi Monte Carlo, Reorder Point, Safety Stock.

\begin{abstract}
PT. ZXC is a company engaged in sales (showroom) and After Sales Service including the sale of spare parts (Vehicle Service Part). In the field of spare parts there are various categories for each spare parts based on demand or movement, which is fast moving, slow moving, non-moving (dead stock), and new models. The ordering system at the company to fill the inventory is not based on the number of requests that will come. The study was conducted in order to be able to assist these companies in order to achieve total sales by proposing improvements in ordering spare parts in the fast moving category using Monte Carlo simulation. This research is also expected to help the company to be able to do the planning and control of consumer demand with notice the reorder point and safety stock resulting from the Monte Carlo simulation. In this study the parts that will be examined, namely Air Cleaner, Oil Filters and Spark Plug because the part is a fast moving part highs. In this study, using a Monte Carlo simulation increase total sales which is viewed by a profit each month. In 2013 until June 2015, the highest increase is equal to $2.622 \%$ and the lowest increase amounted to $0.117 \%$.
\end{abstract}

Keywords: Spare Parts, Ordering Systems, Monte Carlo Simulation, Reorder Points, Safety Stock.

\section{PENDAHULUAN}

PT. ZXC merupakan salah satu jaringan dealer dan workshop yang bergerak di bidang sales (showroom) dan After Sales Service termasuk penjualan spare part (Vehicle Service Part). Pada bidang spare part terdapat berbagai kategori yang ada untuk tiap spare parts berdasarkan demand atau pergerakannya, yaitu fast moving, slow moving, non moving (dead stock), dan new model.

Permasalahan yang ada pada PT. ZXC ini, yaitu dimana performansi penjualan spare parts yang ditentukan hampir tidak pernah tercapai berdasarkan data penjualan dari Januari 2012 sampai dengan Juni 2015. Tidak tercapainya performansi penjualan dikarenakan oleh pemesanan yang kurang baik pada spare parts kategori fast moving. Sistem pemesanan yang dilakukan tidak berdasarkan pada jumlah permintaan yang akan datang.

Penelitian yang dilakukan hanya pada bagian persediaan spare parts untuk beberapa parts yang tergolong kategori fast moving. Data penelitian yang diambil merupakan dari hasil 
penjualan tiga parts kategori fast moving yang akan diteliti dari tanggal 1 Januari 2013 sampai 30 Juni 2015, yaitu air cleaner, oil filter, dan spark plug.

Penelitian ini dilakukan untuk dapat membantu perusahaan ini agar dapat meningkatkan total penjualan. Salah satu metode yang dapat dilakukan pada pengendalian persediaan adalah dengan simulasi Monte Carlo. Hasil dari simulasi Monte Carlo akan dicari nilai Reorder Point dan Safety Stock sehingga perusahaan dapat melakukan perencanaan dan pengendalian terhadap permintaan konsumen dengan memperhatikan reorder point dan safety stock yang dihasilkan dari simulasi Monte Carlo dan diharapkan jumlah barang tidak menumpuk dan juga tidak kekurangan saat dibutuhkan oleh konsumen.

Salah satu model simulasi yang paling terkenal/populer pada pengendalian persediaan adalah simulasi Monte Carlo. Simulasi Monte Carlo dikenal juga dengan istilah Sampling Simulation atau Monte Carlo Sampling Technique. Sampling simulation ini menggambarkan kemungkinan penggunaan data sampel dalam metode Monte Carlo dan juga sudah dapat diketahui atau diperkirakan distribusinya [1]. Model simulasi Monte Carlo merupakan sebuah bentuk simulasi probabilistik dimana solusi dari suatu masalah diberikan berdasarkan proses randomisasi (acak) [2]. Simulasi ini menggunakan data yang sudah ada (historical data). Dengan kata lain, apabila menghendaki model simulasi yang mengikutsertakan random dan sampling dengan distribusi probabilitas yang dapat diketahui dan ditentukan maka cara simulasi Monte Carlo ini dapat dipergunakan.

Bilangan acak adalah bilangan yang kemunculannya terjadi secara acak, bilangan acak sangat berfungsi untuk keperluan simulasi. Bilangan random yang dibangkitkan oleh komputer adalah bilangan acak semu (pseudo random number) [3]. Metode yang biasa digunakan untuk mendapatkan bilangan acak semu, yaitu Linear Congruential Generator. Persamaan yang digunakan adalah:

$Z_{i}=a Z_{i-1}+c(\bmod m)$
Persamaan ini disebut dengan mixed congruential random number generator. Bentuk lain yang juga biasa digunakan adalah multiplicative congruential random number generator. Persamaan yang digunakan adalah:

$Z_{n+1}=a Z_{n}(\bmod m)$

Model simulasi yang dibangun harus kredibel. Representasi kredibel sistem nyata oleh model simulasi ditunjukkan oleh validasi model. Validasi model adalah proses pemeriksaan untuk mengetahui suatu data (model dan sistem nyata) valid atau tidak. Model dikatakan valid apabila hasil perbandingan menunjukkan bahwa kedua alternatif (model dan real system) tidak berbeda secara signifikan. Terdapat dua metode yang dapat digunakan untuk membandingkan dua alternatif disain sistem, yaitu: Welch Confidence Interval dan Paired-t Confidence.

Model simulasi Monte Carlo sangat cocok digunakan untuk data dengan pola random/acak. Untuk dapat mengetahui/ observasi pola data pada periode waktu yang berbeda sering berhubungan atau berkorelasi.

Reoder Point adalah suatu tanda yang menunjukkan kepada perusahaan akan saatnya untuk melakukan pemesanan kembali atas suatu produk [4]. Apabila perusahaan tidak melakukan pemesanan pada titik pemesanan kembali maka akan dapat menyebabkan terjadinya kehabisan stock (stock out). Sedangkan safety stock adalah tingkat persediaan minimal yang harus selalu ada pada setiap periode, sehingga perusahaan dapat mengantisipasi apabila terjadi lonjakan permintaan atau keterlambatan pengiriman.

\section{METODE PENELITIAN}

Metodologi penelitian merupakan tahaptahap penelitian yang harus dilakukan, sehingga penelitian dapat dilakukan dengan terarah dan mempermudah analisis permasalahan yang ada. Metodologi penelitian yang akan dilakukan adalah sebagai berikut: 
Optimasi Persediaan Spare Part untuk Meningkatkan Total Penjualan dengan Menggunakan Simulasi Monte Carlo (Studi Kasus di PT. ZXC)

Iphov Kumala, I Wayan Sukania dan Santo Christianto

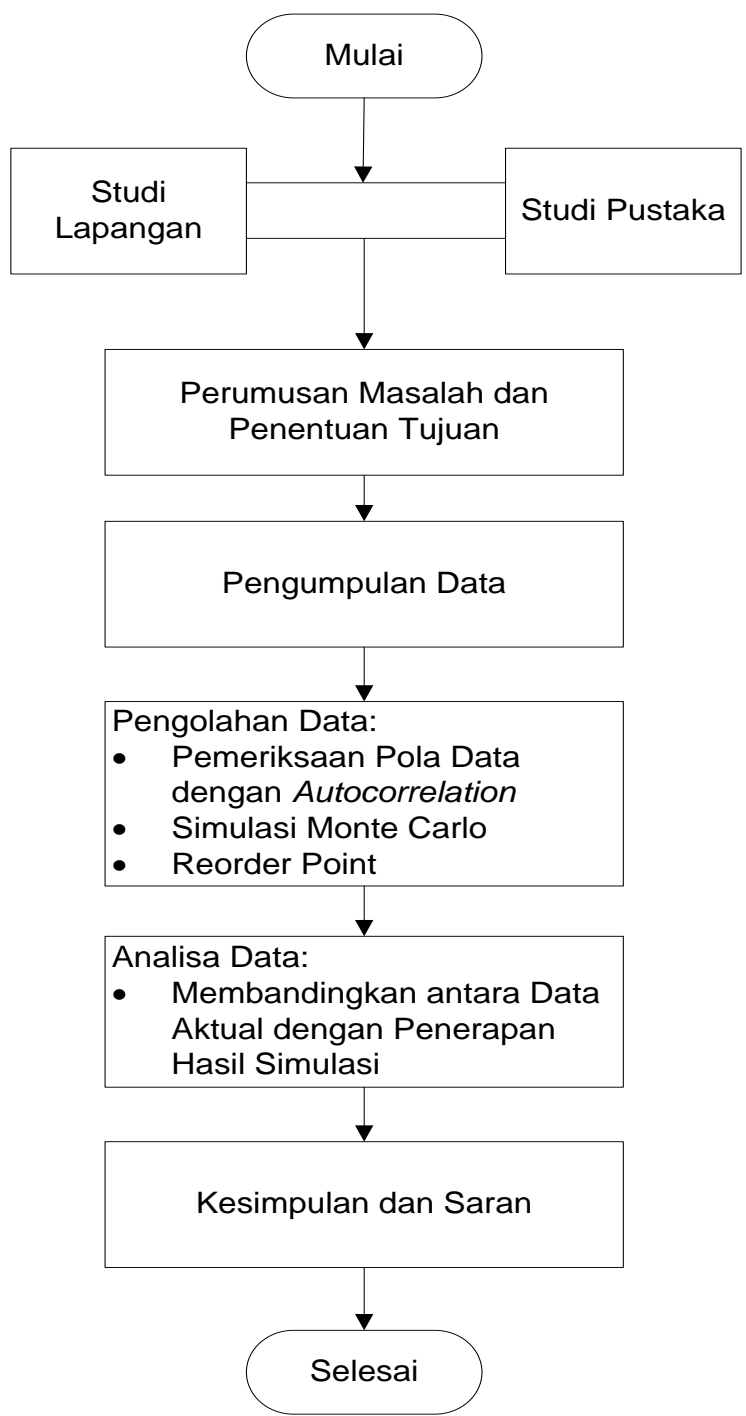

Gambar 1. Flowchart Metode Penelitian

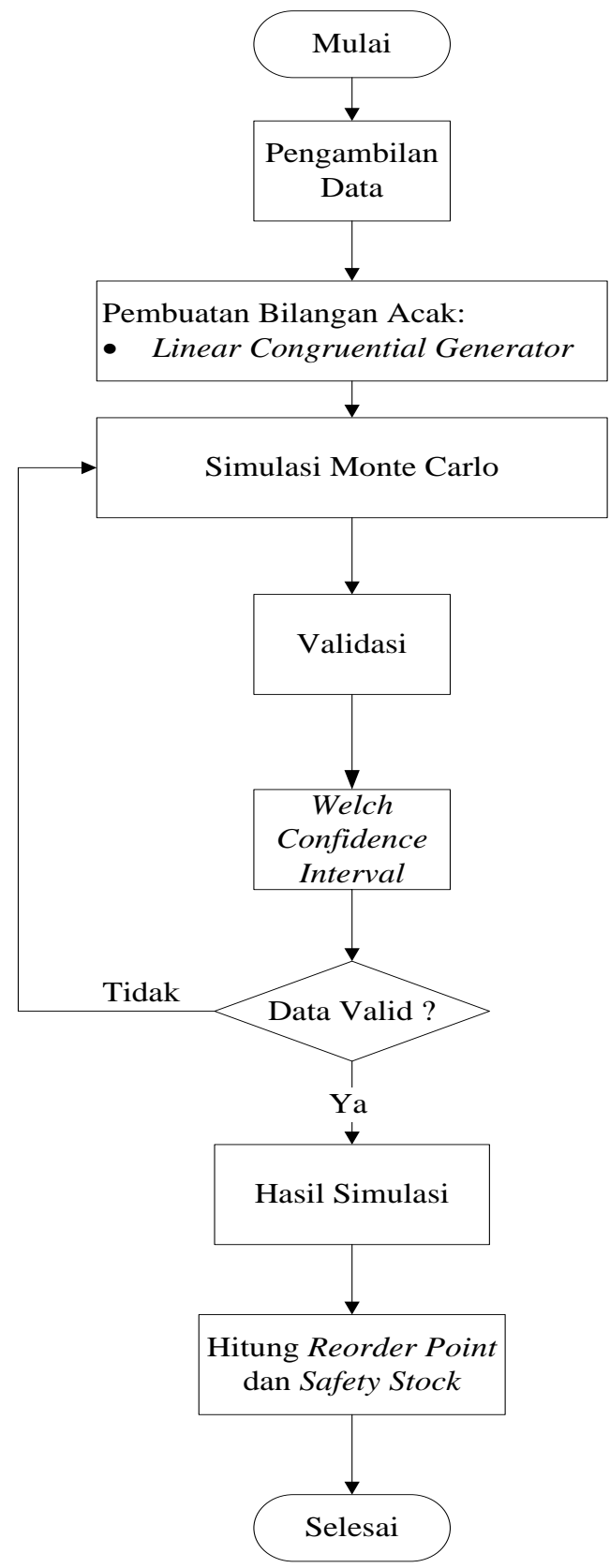

Gambar 2. Flowchart Pengolahan Data

\section{HASIL DAN PEMBAHASAN}

Kebijakan pemesanan yang sudah ditetapkan perusahaan terdapat 4 jenis pemesanan, yaitu Just-in-time, Regular Order, EO Follow, dan Vehicle Off Road (VOR). Karakteristik tiap pemesanan dijelaskan pada Tabel 1. Karakteristik tiap part dijelaskan pada Tabel 2.

Tabel 1. Karakteristik Tipe Order

\begin{tabular}{ccc}
\hline Tipe Order & HPP (\%) & Lead Time (hari) \\
\hline JIT & 68 & 3 \\
RO & 72 & 2 \\
VOR & 78 & 1 \\
\hline
\end{tabular}

Tabel 1. Karakteristik Tiap Part

\begin{tabular}{ccc}
\hline Spare Part & Stock Level & Harga Part \\
\hline Air Cleaner & 20 & $\mathrm{Rp} 130.000,00$ \\
Oil Filter & 100 & $\mathrm{Rp} 35.000,00$ \\
Spark Plug & 110 & $\mathrm{Rp} 30.000,00$ \\
\hline
\end{tabular}

Data performansi spare part pada perusahaan dari tahun 2013 hingga Juni 2015 dapat dilihat pada Tabel 3, Tabel 4 dan Tabel 5.

Data yang ingin diteliti merupakan data dengan pola acak. Untuk mengetahui pola data maka dilakukan pengujian dengan metode autokorelasi. Berdasarkan hasil uji autokorelasi pada data air cleaner, oil filter, dan spark plug 
Tabel 3. Performansi Spare Part 2013

\begin{tabular}{ccccccc}
\hline Subjek & Jan & Feb & Mar & Apr & Mei & Jun \\
\hline Target & Rp 258.982.000 & Rp 276.956.000 & Rp 263.679.000 & Rp 259.879.000 & Rp 272.367.000 & Rp 268.768.000 \\
Total Sales & Rp 243.476.022 & Rp 247.871.220 & Rp 264.675.120 & Rp 252.675.891 & Rp 257.987.180 & Rp 259.812.371 \\
\cline { 2 - 7 } & Jul & Ags & Sep & Okt & Nov & Des \\
\cline { 2 - 7 } & Rp 274.576.000 & Rp 297.589.000 & Rp 256.848.900 & Rp 262.867.000 & Rp 272.743.000 & Rp 309.756.000 \\
& Rp 267.812.300 & Rp 295.528.055 & Rp 248.755.122 & Rp 256.814.176 & Rp 264.651.171 & Rp 297.181.910 \\
\cline { 2 - 6 }
\end{tabular}

Tabel 4. Performansi Spare Part 2014

\begin{tabular}{ccccccc}
\hline Subjek & Jan & Feb & Mar & Apr & Mei & Jun \\
\hline Target & Rp 288.236.000 & Rp 282.302.000 & Rp 292.585.000 & Rp 302.398.000 & Rp 272.187.000 & Rp 296.935.000 \\
Total Sales & Rp 296.500.738 & Rp 256.686.261 & Rp 270.494.033 & Rp 251.370.449 & Rp 244.255.349 & Rp 251.409.262 \\
\hline & Jul & Ags & Sep & Okt & Nov & Des \\
\cline { 2 - 7 } & Rp 288.574.000 & Rp 272.953.000 & Rp 307.252.000 & Rp 321.654.000 & Rp 297.185.000 & Rp 319.954.000 \\
& Rp 333.033.014 & Rp 281.470.545 & Rp 230.811.191 & Rp 212.102.377 & Rp 221.383.495 & Rp 230.170.944 \\
\cline { 2 - 6 }
\end{tabular}

Tabel 5. Performansi Spare Part 2015

\begin{tabular}{ccccccc}
\hline Subjek & Jan & Feb & Mar & Apr & Mei & Jun \\
\hline Target & Rp 265.332.000 & Rp 293.129.000 & Rp 286.509.000 & Rp 260.632.000 & Rp 272.893.000 & Rp 296.127.000 \\
Total Sales & Rp 243.290.237 & Rp 224.419.661 & Rp 257.198.145 & Rp 246.407.596 & Rp 249.129.416 & Rp 291.541.896 \\
\hline
\end{tabular}

bahwa data merupakan data dengan pola acak. Data merupakan pola acak dikarenakan semua nilai ACF mendekati nol. Hasil uji autokorelasi akan dijelaskan pada Gambar 3, 4, dan 5.

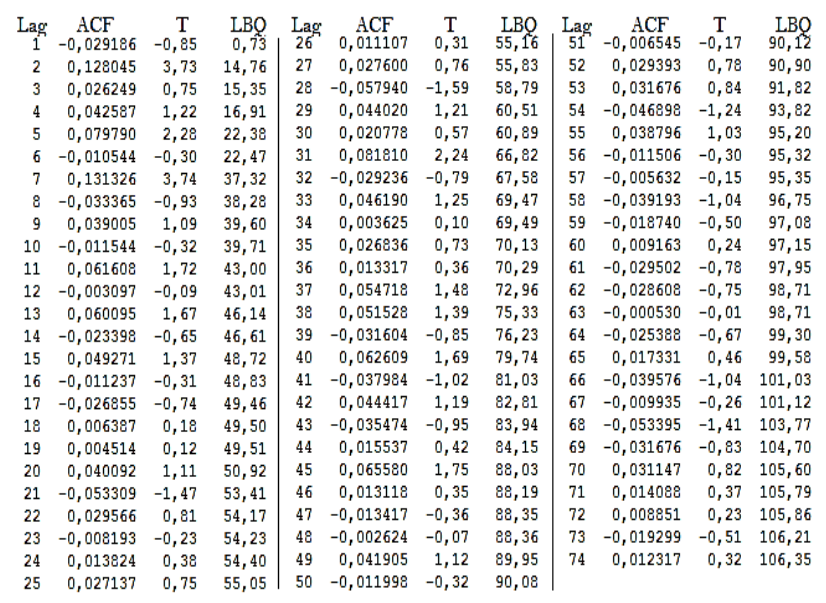

Gambar 3. Uji Pola Data Air Cleaner

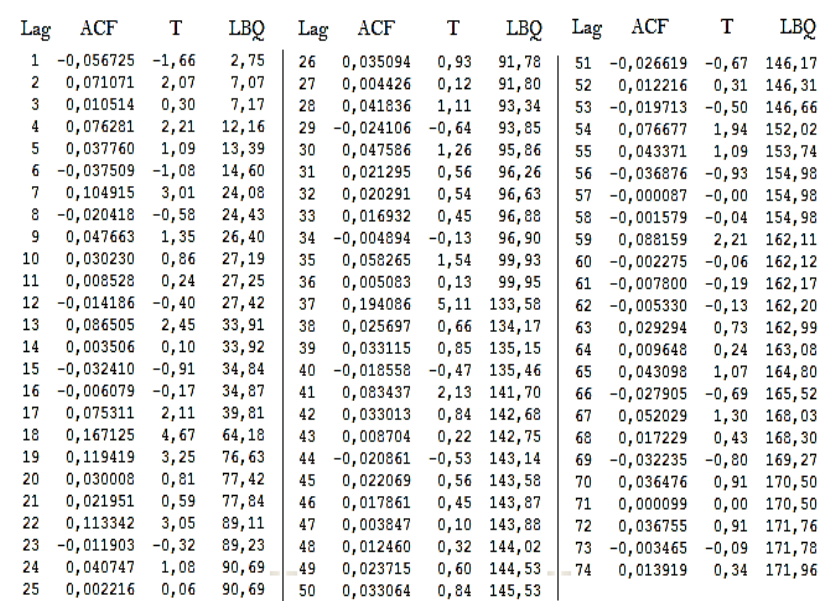

Gambar 4. Uji Pola Data Oil Filter

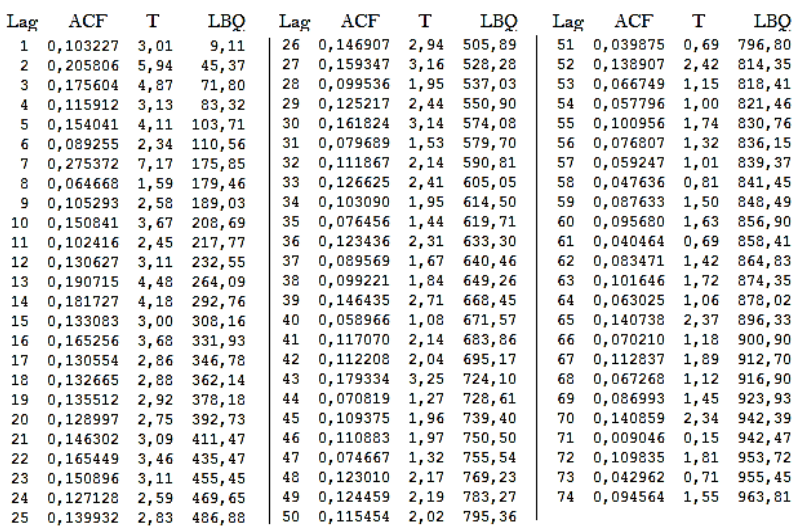

Gambar 5. Uji Pola Data Spark Plug

Tabel 5. Bilangan Acak

\begin{tabular}{cccccccccc}
\hline 5 & 71 & 77 & 7 & 80 & 69 & 68 & 15 & 19 & 37 \\
25 & 64 & 94 & 35 & 12 & 54 & 49 & 75 & 95 & 88 \\
28 & 29 & 82 & 78 & 60 & 76 & 51 & 84 & 87 & 52 \\
43 & 48 & 22 & 2 & 9 & 89 & 61 & 32 & 47 & 66 \\
21 & 46 & 13 & 10 & 45 & 57 & 14 & 63 & 41 & 39 \\
8 & 36 & 65 & 50 & 31 & 91 & 70 & 24 & 11 & 1 \\
40 & 83 & 34 & 56 & 58 & 67 & 59 & 23 & 55 & 5 \\
6 & 27 & 73 & 86 & 96 & 44 & 4 & 18 & 81 & 25 \\
30 & 38 & 74 & 42 & 92 & 26 & 20 & 99 & 17 & 28 \\
53 & 93 & 79 & 16 & 72 & 33 & 3 & 62 & 85 & 43 \\
\hline
\end{tabular}

Dapat dilihat dari ketiga Gambar di atas bahwa ketiga part memiliki pola data acak yang dikarenakan nilai ACF (autocorrelation function) mendekati nol. Untuk dapat melakukan simulasi, maka perlu dibuat bilangan acak terlebih dahulu. Pembuatan bilangan acak yang dibentuk berdasarkan dengan $\mathrm{a}=5, \mathrm{~m}=97$,dan $\mathrm{Z}_{0}=1$. 
Optimasi Persediaan Spare Part untuk Meningkatkan Total Penjualan dengan Menggunakan Simulasi Monte Carlo (Studi Kasus di PT. ZXC)

Iphov Kumala, I Wayan Sukania dan Santo Christianto

Tabel 6. Distribusi Permintaan Air Cleaner

\begin{tabular}{ccccc}
\hline Permintaan & Frekuensi & $\begin{array}{c}\text { Frekuensi } \\
\text { Kumulatif }\end{array}$ & $\begin{array}{c}\text { Probabilitas } \\
\text { Kumulatif }\end{array}$ & $\begin{array}{c}\text { Range Bilangan } \\
\text { Acak }\end{array}$ \\
\hline 0 & 133 & 133 & 0,156 & $0-14$ \\
1 & 231 & 364 & 0,427 & $15-41$ \\
2 & 192 & 556 & 0,653 & $42-64$ \\
$\ldots$ & $\ldots$ & $\ldots$ & $\ldots$ & $\ldots$ \\
6 & 19 & 831 & 0,975 & $95-96$ \\
7 & 11 & 842 & 0,988 & $97-98$ \\
15 & 10 & 852 & 1,000 & 99 \\
\hline
\end{tabular}

Tabel 7. Distribusi Permintaan Oil Filter

\begin{tabular}{ccccc}
\hline Permintaan & Frekuensi & $\begin{array}{c}\text { Frekuensi } \\
\text { Kumulatif }\end{array}$ & $\begin{array}{c}\text { Probabilitas } \\
\text { Kumulatif }\end{array}$ & $\begin{array}{c}\text { Range Bilangan } \\
\text { Acak }\end{array}$ \\
\hline 5 & 19 & 19 & 0,022 & $0-2$ \\
6 & 21 & 40 & 0,047 & $3-4$ \\
7 & 10 & 50 & 0,059 & $5-6$ \\
$\ldots$ & $\ldots$ & $\ldots$ & $\ldots$ & $\ldots$ \\
36 & 13 & 824 & 0,972 & $96-97$ \\
48 & 19 & 843 & 0,994 & 98 \\
74 & 5 & 848 & 1,000 & 99 \\
\hline
\end{tabular}

Tabel 8. Distribusi Permintaan Spark Plug

\begin{tabular}{ccccc}
\hline Permintaan & Frekuensi & $\begin{array}{c}\text { Frekuensi } \\
\text { Kumulatif }\end{array}$ & $\begin{array}{c}\text { Probabilitas } \\
\text { Kumulatif }\end{array}$ & $\begin{array}{c}\text { Range Bilangan } \\
\text { Acak }\end{array}$ \\
\hline 0 & 81 & 81 & 0,095 & $0-9$ \\
4 & 101 & 182 & 0,214 & $10-21$ \\
8 & 106 & 288 & 0,338 & $22-33$ \\
12 & 113 & 401 & 0,471 & $34-47$ \\
$\ldots$ & $\ldots$ & $\ldots$ & $\ldots$ & $\ldots$ \\
36 & 25 & 803 & 0,942 & $92-94$ \\
40 & 20 & 823 & 0,966 & $95-96$ \\
48 & 16 & 839 & 0,985 & $97-98$ \\
66 & 13 & 852 & 1,000 & 99 \\
\hline
\end{tabular}

Setelah didapatkan bilangan acak, kemudian dari data permintaan pada tiap part disusun distribusinya sehingga menunjukkan peluang kejadian berdasarkan selang kelas. Distribusi permintaan aktual dijelaskan pada Tabel 6, 7, dan 8.

Apabila bilangan acak yang dibangkitkan pada simulasi terdapat pada range 0-14 (termasuk 0 dan 14), maka jumlah permintaan untuk part air cleaner adalah sebanyak 0 buah. Jika bilangan acak yang dibangkitkan pada simulasi terdapat pada range 15-41 (termasuk 15 dan 41), maka jumlah permintaan untuk part air cleaner adalah sebanyak 1 buah.

Apabila bilangan acak yang dibangkitkan pada simulasi terdapat pada range 0-2 (termasuk 0 dan 2), maka jumlah permintaan untuk part oil filter adalah sebanyak 5 buah. Jika bilangan acak yang dibangkitkan pada simulasi terdapat pada range 3 dan 4, maka jumlah permintaan untuk part oil filter adalah sebanyak 6 buah.

Apabila bilangan acak yang dibangkitkan pada simulasi terdapat pada range 0-9 (termasuk 0 dan 9), maka jumlah permintaan untuk part spark plug adalah sebanyak 0 buah. Jika bilangan acak yang dibangkitkan pada simulasi terdapat pada range 10-21 (termasuk 10 dan 21), maka jumlah permintaan untuk part spark plug adalah sebanyak 4 buah.

Simulasi tiap part dilakukan sebanyak 30 kali agar sesuai dengan data aktual yang ada selama 30 bulan dimana di setiap simulasinya sebanyak 30 hari. Hasil dari simulasi pada ketiga part dapat dilihat pada Tabel 9, 10, dan Tabel 11. 
Tabel 9. Simulasi Air Cleaner

\begin{tabular}{ccc}
\hline Hari & Bilangan Acak & $\begin{array}{c}\text { Permintaan } \\
\text { (Simulasi) }\end{array}$ \\
\hline 1 & 5 & 0 \\
2 & 25 & 1 \\
3 & 28 & 1 \\
$\ldots$ & $\ldots$ & $\ldots$ \\
28 & 73 & 3 \\
29 & 74 & 3 \\
30 & 79 & 4 \\
\hline \multicolumn{2}{c}{ Ratandar Deviasi } & 2,000 \\
\hline Varian & 1,486 \\
\hline \multicolumn{2}{c}{}
\end{tabular}

Tabel 10. Simulasi Oil Filter

\begin{tabular}{ccc}
\hline Hari & Bilangan Acak & $\begin{array}{c}\text { Permintaan } \\
\text { (Simulasi) }\end{array}$ \\
\hline 1 & 5 & 7 \\
2 & 25 & 13 \\
3 & 28 & 14 \\
$\ldots$ & $\ldots$ & $\ldots$ \\
28 & 73 & 24 \\
29 & 74 & 24 \\
30 & 79 & 25 \\
\hline \multicolumn{3}{c}{ Rata-rata } \\
\hline Standar Deviasi & 18,77 \\
\hline Varian & 8,964 \\
\hline
\end{tabular}

Tabel 11. Simulasi Spark Plug

\begin{tabular}{ccc}
\hline Hari & Bilangan Acak & $\begin{array}{c}\text { Permintaan } \\
\text { (Simulasi) }\end{array}$ \\
\hline 1 & 5 & 0 \\
2 & 25 & 8 \\
3 & 28 & 4 \\
$\ldots$ & $\ldots$ & $\ldots$ \\
28 & 73 & 24 \\
29 & 74 & 24 \\
30 & 79 & 24 \\
\hline \multicolumn{3}{c}{ Rata-rata } \\
\hline Standar Deviasi & 14,667 \\
\hline Varian & 10,310 \\
\hline
\end{tabular}

Tabel 12. WCI Air Cleaner

\begin{tabular}{ccc}
\hline \multirow{2}{*}{ Replikasi } & $\begin{array}{c}\text { Sistem Nyata } \\
(\bar{X})\end{array}$ & $\begin{array}{c}\text { Sistem Simulasi } \\
(\bar{X})\end{array}$ \\
\hline 1 & 1,966 & 2,000 \\
2 & 2,480 & 2,233 \\
3 & 2,483 & 2,367 \\
$\ldots$ & $\ldots$ & $\ldots$ \\
28 & 2,143 & 2,433 \\
29 & 2,148 & 2,167 \\
30 & 2,862 & 2,767 \\
\hline Rata-rata & 2,179 & 2,136 \\
\hline Standar Deviasi & 0,481 & 0,310 \\
\hline Varian & 0,232 & 0,096 \\
\hline
\end{tabular}

Hasil simulasi dilakukan uji validitas dengan menggunakan welch confidence interval. Berikut di bawah ini merupakan uji validitas dengan welch confidence interval.

Tabel 13. WCI Oil Filter

\begin{tabular}{ccc}
\hline Replikasi & $\begin{array}{c}\text { Sistem Nyata } \\
(\bar{X})\end{array}$ & $\begin{array}{c}\text { Sistem Simulasi } \\
(\bar{X})\end{array}$ \\
\hline 1 & 22,069 & 18,200 \\
2 & 22,920 & 19,300 \\
3 & 23,828 & 19,767 \\
$\ldots$ & $\ldots$ & $\ldots$ \\
28 & 23,000 & 17,467 \\
29 & 17,074 & 19,000 \\
30 & 20,897 & 19,033 \\
\hline Rata-rata & 19,844 & 18,793 \\
\hline Standar Deviasi & 2,942 & 1,275 \\
\hline Varian & 8,656 & 1,627 \\
\hline
\end{tabular}

Tabel 14. WCI Spark Plug

\begin{tabular}{ccc}
\hline Replikasi & $\begin{array}{c}\text { Sistem Nyata } \\
(\bar{X})\end{array}$ & $\begin{array}{c}\text { Sistem Simulasi } \\
(\bar{X})\end{array}$ \\
\hline 1 & 25,966 & 14,667 \\
2 & 24,640 & 16,533 \\
3 & 25,379 & 16,467 \\
$\ldots$ & $\ldots$ & $\ldots$ \\
28 & 9,714 & 13,867 \\
29 & 11,333 & 17,067 \\
30 & 18,207 & 14,400 \\
\hline Rata-rata & 16,807 & 15,876 \\
\hline Standar Deviasi & 5,229 & 1,639 \\
\hline Varian & 27,346 & 2,685 \\
\hline
\end{tabular}

Hipotesa:

$$
\begin{aligned}
& \mathrm{H}_{0}: \mu_{(1-2)}=0 \\
& \mathrm{H}_{1}: \mu_{(1-2)} \neq 0
\end{aligned}
$$

Dengan $\alpha=5 \%$, maka didapatkan nilai:

Confidence interval:

$$
\begin{aligned}
(2,179-2,136)-0,106 & \leq \mu_{(1-2)} \leq(2,179-2,136)+0,106 \\
-0,063 & \leq \mu_{(1-2)} \leq 0,149
\end{aligned}
$$

Kesimpulan: terima $\mathrm{H}_{0}$ atau rata-rata permintaan part air cleaner tiap bulan pada sistem nyata sama dengan model simulasi.

Hipotesa:

$$
\begin{aligned}
& \mathrm{H}_{0}: \mu_{(1-2)}=0 \\
& \mathrm{H}_{1}: \mu_{(1-2)} \neq 0
\end{aligned}
$$

Dengan $\alpha=5 \%$, maka didapatkan nilai:

Confidence interval:

$(19,844-18,793)-0,749 \leq \mu_{(1-2)} \leq(19,844-18,793)+3,749$

$$
-2,698 \leq \mu_{(1-2)} \leq 4,800
$$


Kesimpulan: terima $\mathrm{H}_{0}$ atau rata-rata permintaan part oil filter tiap bulan pada sistem nyata sama dengan model simulasi.

Hipotesa:

$$
\begin{aligned}
& \mathrm{H}_{0}: \mu_{(1-2)}=0 \\
& \mathrm{H}_{1}: \mu_{(1-2)} \neq 0
\end{aligned}
$$

Dengan $\alpha=5 \%$, maka didapatkan nilai:

Confidence interval:

$(16,807-15,876)-11,765 \leq \mu_{(1-2)} \leq(16,807-15,876)$

$$
-10,833 \leq \mu_{(1-2)} \leq 12,696
$$

Kesimpulan: terima $\mathrm{H}_{0}$ atau rata-rata permintaan part spark plug tiap bulan pada sistem nyata sama dengan model simulasi.

Penentuan reorder point dan safety stock didapatkan berdasarkan dari hasil simulasi sebanyak 30 kali pada masing-masing part. Nilai reorder point dan safety stock pada tiap part dapat dilihat sebagai berikut:

Jumlah persediaan minimal (safety stock) yang harus disediakan setiap hari untuk air cleaner adalah:

$\mathrm{ROP}=2,136 \times 2,5+$

ROP $=10,583$ unit

$$
1,645 \sqrt{2,5\left(1,775^{2}\right)+2,136^{2}\left(0,707^{2}\right)}
$$

Jumlah persediaan minimal (safety stock) yang harus disediakan setiap hari untuk oil filter adalah:

$\mathrm{ROP}=18,793 \times 2,5+$

$$
1,645 \sqrt{2,5\left(8,424^{2}\right)+18,793^{2}\left(0,707^{2}\right)}
$$

ROP $=77,931$ unit

Jumlah persediaan minimal (safety stock) yang harus disediakan setiap hari untuk spark plug adalah:

$\mathrm{ROP}=15,876 \times 2,5+$

ROP $=74,314$ unit

$$
1,645 \sqrt{2,5\left(11,262^{2}\right)+15,876^{2}\left(0,707^{2}\right)}
$$

Langkah berikutnya setelah penentuan reorder point dan safety stock, yaitu dengan melakukan analisa perbandingan antara data aktual dengan penerapan hasil simulasi yang dapat dilhat pada Tabel 15 dan 16.

Dapat dilihat pada Tabel 15 dan Tabel 16, total keuntungan penjualan pada Tabel 15 adalah sebesar Rp2.730.000,00 dan total keuntungan penjualan pada Tabel 16 adalah sebesar Rp3.265.600,00. Perbandingan total keuntungan antara data aktual dengan penerapan simulasi adalah sebesar Rp535.600,00 dimana meningkat sebanyak 19,619\% dari Rp2.730.000,00 menjadi Rp3.265.600,00. Peningkatan total keuntungan ini jelas akan mempengaruhi terhadap peningkatan total penjualan pada performansi spare part. Perbandingan penerapan yang dilakukan pada ketiga part yang diteliti pada

\begin{tabular}{|c|c|c|c|c|c|c|c|c|c|c|}
\hline No & $\begin{array}{c}\text { Unit } \\
\text { yang } \\
\text { diterima }\end{array}$ & $\begin{array}{c}\text { Persediaan } \\
\text { awal }\end{array}$ & $\begin{array}{c}\text { Permin } \\
\text { taan }\end{array}$ & $\begin{array}{c}\text { Persediaan } \\
\text { Akhir }\end{array}$ & $\begin{array}{c}\text { Pesan/ } \\
\text { Tidak }\end{array}$ & $\begin{array}{c}\text { Jumlah } \\
\text { Pemesanan }\end{array}$ & $\begin{array}{l}\text { Lead } \\
\text { Time }\end{array}$ & Total Cost & Harga Jual & Keuntungan \\
\hline 2 & 0 & 29 & 1 & 28 & Tidak & - & - & - & Rp 130000 & Rp130000 \\
\hline 3 & 0 & 28 & 1 & 27 & Tidak & - & - & - & Rp 130000 & Rp130000 \\
\hline 4 & 0 & 27 & 2 & 25 & Tidak & - & - & - & Rp260000 & Rp260000 \\
\hline 5 & 0 & 25 & 3 & 22 & Tidak & - & - & - & Rp390000 & Rp390000 \\
\hline$\ldots$ & $\ldots$ & $\ldots$ & .. & $\ldots$ & $\ldots$ & $\ldots$ & $\ldots$ & $\ldots$ & $\ldots$ & $\ldots$ \\
\hline 27 & 0 & 26 & 1 & 25 & Tidak & - & - & - & Rp130000 & Rp130000 \\
\hline 28 & 0 & 25 & 5 & 20 & $\begin{array}{l}\text { Reguler } \\
\text { Order }\end{array}$ & 5 & 2 & Rp 468.000 & Rp650000 & Rp182000 \\
\hline 29 & 0 & 20 & 3 & 17 & $\begin{array}{l}\text { Reguler } \\
\text { Order }\end{array}$ & 5 & 2 & Rp 468.000 & Rp390000 & $\mathrm{Rp}(78000)$ \\
\hline 30 & 0 & 22 & 1 & 21 & Tidak & - & - & & Rp130000 & Rp130000 \\
\hline 31 & 0 & 26 & 4 & 22 & Tidak & - & - & & Rp520000 & Rp520000 \\
\hline & & & & & & & & & Total & Rp2730000 \\
\hline
\end{tabular}
bulan Januari 2013 hingga bulan Juni 2015. Setelah dilakukan penerapan hasil simulasi pada ketiga part, perbandingan keseluruhan dapat dilihat seperti pada Tabel 17.

Tabel 15. Data Aktual Permintaan Air Cleaner Januari 2013 
Tabel 16. Penerapan Simulasi Air Cleaner Januari 2013

\begin{tabular}{|c|c|c|c|c|c|c|c|c|c|c|}
\hline No & $\begin{array}{l}\text { Unit yang } \\
\text { diterima }\end{array}$ & $\begin{array}{l}\text { Persediaan } \\
\text { awal }\end{array}$ & $\begin{array}{c}\text { Permin } \\
\text { taan }\end{array}$ & $\begin{array}{l}\text { Persediaan } \\
\text { Akhir }\end{array}$ & $\begin{array}{l}\text { Pesan/ } \\
\text { Tidak }\end{array}$ & $\begin{array}{c}\text { Jumlah } \\
\text { Pemesanan }\end{array}$ & $\begin{array}{l}\text { Lead } \\
\text { Time }\end{array}$ & Total Cost & Harga Jual & Keuntungan \\
\hline 2 & 0 & 29 & 1 & 28 & Tidak & - & - & - & Rp 130000 & Rp130000 \\
\hline 3 & 0 & 28 & 1 & 27 & Tidak & - & - & - & Rp 130000 & Rp130000 \\
\hline 4 & 0 & 27 & 2 & 25 & Tidak & - & - & - & Rp260000 & Rp260000 \\
\hline. & $\ldots$ & $\ldots$ & $\ldots$ & $\ldots$ & $\cdots$ & $\ldots$ & $\ldots$ & $\ldots$ & & \\
\hline 27 & 0 & 13 & 1 & 12 & Tidak & - & - & - & Rp130000 & Rp130000 \\
\hline 28 & 0 & 12 & 5 & 7 & $\begin{array}{l}\text { Just In } \\
\text { Time }\end{array}$ & 13 & 3 & Rp1149200 & Rp650000 & Rp(499200 \\
\hline 29 & 0 & 7 & 3 & 4 & VOR & 6 & 1 & Rp 608400 & Rp390000 & $\operatorname{Rp}(218400)$ \\
\hline 30 & 6 & 10 & 1 & 9 & Tidak & - & - & & Rp130000 & Rp130000 \\
\hline 31 & 13 & 22 & 4 & 18 & Tidak & - & - & & Rp520000 & Rp520000 \\
\hline & & & & & & & & & Total & Rp3265600 \\
\hline
\end{tabular}

Tabel 17. Rincian Peningkatan Total Penjualan

\begin{tabular}{|c|c|c|c|c|c|c|c|c|c|c|c|c|c|}
\hline & Bulan & $\begin{array}{c}\text { Jan } \\
\% \\
\end{array}$ & $\begin{array}{c}\text { Feb } \\
\%\end{array}$ & $\begin{array}{c}\text { Mar } \\
\%\end{array}$ & $\begin{array}{c}\text { Apr } \\
\%\end{array}$ & $\begin{array}{c}\text { Mei } \\
\% \\
\end{array}$ & $\begin{array}{c}\text { Jun } \\
\%\end{array}$ & $\begin{array}{c}\text { Juli } \\
\%\end{array}$ & $\begin{array}{c}\text { Ags } \\
\%\end{array}$ & $\begin{array}{c}\text { Sep } \\
\%\end{array}$ & $\begin{array}{c}\text { Okt } \\
\%\end{array}$ & $\begin{array}{c}\text { Nov } \\
\%\end{array}$ & $\begin{array}{c}\text { Des } \\
\%\end{array}$ \\
\hline \multirow{2}{*}{2013} & $\begin{array}{l}\text { Peningkatan } \\
\text { per bulan }\end{array}$ & 36,64 & 13,75 & 2,83 & 6,19 & 3,49 & 34,25 & 19,56 & 19,55 & 3,87 & 5,53 & 57,63 & 9,84 \\
\hline & $\begin{array}{l}\text { Peningkatan } \\
\text { Total Sales }\end{array}$ & 2,33 & 0,60 & 0,18 & 0,37 & 0,21 & 1,56 & 1,00 & 2,23 & 0,30 & 1,68 & 0,44 & 0,36 \\
\hline \multirow{2}{*}{2014} & $\begin{array}{l}\text { Peningkatan } \\
\text { per bulan }\end{array}$ & 14,41 & 12,83 & 3,35 & 23,18 & 3,27 & 145,85 & 4,81 & 16,61 & 8,05 & 21,38 & 2,15 & 6,18 \\
\hline & $\begin{array}{l}\text { Peningkatan } \\
\text { Total Sales }\end{array}$ & 0,46 & 0,52 & 0,17 & 0,87 & 2,62 & 2,62 & 0,27 & 0,59 & 0,41 & 0,88 & 0,12 & 0,34 \\
\hline \multirow{2}{*}{2015} & $\begin{array}{l}\text { Peningkatan } \\
\text { per bulan }\end{array}$ & 42,99 & 19,47 & 7,61 & 48,42 & 24,45 & 4,54 & & & & & & \\
\hline & $\begin{array}{l}\text { Peningkatan } \\
\text { Total Sales }\end{array}$ & 1,28 & 0,78 & 0,39 & 1,53 & 0,79 & 0,23 & & & & & & \\
\hline
\end{tabular}

Berdasarkan pada Tabel 17, hasil analisis perbandingan antara data aktual penjualan dengan penerapan hasil simulasi, terdapat peningkatan tiap bulannya dari tahun 2013 hingga Juni 2015. Peningkatan pada tahun 2013 secara berturut-turut, yaitu 2,327\%; 0,602\%; $0,184 \%$; $0,367 \% ; 0,214 \% ; 1,558 \% ; 1,003 \%$; 0,230\%; $0,303 \% ; \quad 1,680 \% ; \quad 0,436 \%$; dan 0,363\%. Peningkatan pada tahun 2014 secara berturut-turut, yaitu 0,464\%; 0,519\%; 0,168\%; $0,868 \% ; 0,170 \% ; 2,622 \% ; 0,271 \% ; 0,587 \%$; 0,407\%; 0,879\%; 0,117\%; dan 0,339\%. Peningkatan pada tahun 2015 secara berturutturut, yaitu 1,282\%; 0,784\%; 0,393\%; 1,532\%; $0,789 \%$; dan $0,230 \%$.

\section{KESIMPULAN}

Berdasarkan hasil penelitian yang sudah dilakukan, dapat dilihat bahwa pola data dari ketiga part merupakan data dengan pola acak. Berdasarkan hasil simulasi sebanyak 30 kali pada tiap part, rata-rata permintaan untuk air cleaner sebesar 2,136 buah per hari; oil filter sebesar 18,793 buah per hari; dan spark plug sebesar 15,876 buah per hari. Hasil uji validitas untuk ketiga part dinyatakan menerima $\mathrm{H}_{0}$. Nilai reorder point dan safety stock untuk air cleaner sebesar 11 buah dan 6 buah; untuk oil filter sebesar 78 buah dan 31 buah; dan untuk spark plug sebesar 75 buah dan 35 buah. Hasil analisis perbandingan antara data aktual penjualan dengan penerapan hasil simulasi, terdapat peningkatan tiap bulannya dari tahun 2013 hingga Juni 2015. Peningkatan pada tahun 2013 secara berturut-turut, yaitu 2,327\%; 0,602\%; 0,184\%; 0,367\%; 0,214\%; $1,558 \%$; $1,003 \% ; 0,230 \% ; 0,303 \% ; 1,680 \% ; 0,436 \%$; dan 0,363\%. Peningkatan pada tahun 2014 secara berturut-turut, yaitu $0,464 \% ; 0,519 \%$; $0,168 \% ; 0,868 \%$; $0,170 \%$; 2,622\%; 0,271\%; 0,587\%; $0,407 \% ; \quad 0,879 \% ; \quad 0,117 \%$; dan 0,339\%. Peningkatan pada tahun 2015 secara berturut-turut, yaitu 1,282\%; 0,784\%; 0,393\%; 1,532\%; 0,789\%; dan 0,230\%.

\section{DAFTAR PUSTAKA}

[1] Sugiharto, Bambang. “Aplikasi Simulasi Untuk Peramalan Permintaan Dan Pengelolaan Persediaan Yang Bersifat Probabilistik.” INASEA: Vol. 8 No. 2 (2007): 112 - 120.

[2] Indah, Weny. "Simulasi Produksi Dan Distribusi Pelayanan Permintaan Sarung Tenun Dengan Monte Carlo.” SNASTI (2011): SC - 27.

[3] Rangkuti, Freddy. 2004. Flexible Marketing. Jakarta: Gramedia. 
[4] Alam, M. Agus J. 2003. Mengolah Database dengan Borland Delphi 7. Jakarta: Gramedia.

[5] Edward J, Blocher. 2007. Cost Management $3^{\text {rd }}$ Edition. Jakarta: Salemba Empat.

[6] Griffin,Ricky. 2004. Management $7^{\text {th }}$ Edition. Jakarta: Erlangga.

[7] Hanke dan Winchern. 2005. Bussiness Forecasting. USA: Prentice Hall.

[8] Harris, James (2013) "Some Notes On Multiplicative Congruential Random Number Generators With Mersenne Prime Modulus 261-1.," Journal of the South Carolina Academy of Science: Vol. 1: Iss. 1, Article 10.

[9] Hartini, Sri., Zainal Fanani, dan Luki Rachimi A. "Usulan Sistem Pemesanan Untuk Meningkatkan Service Level Pada Sistem Heijunka.” J@TI UNDIP, Vol III, No 3 (2008).

[10] Herjanto, Eddy. 2008. Manajemen Operasi Edisi Ketiga. Jakarta: Grasindo.

[11] Herjanto, Eddy. 2008. Sains Manajemen. Jakarta: Grasindo.

[12] Iqbal, Hasan. 2002. Pokok-pokok Materi Metodologi Penelitian dan Aplikasinya. Jakarta: Ghalia Indonesia.

[13] P, Siagian. 1987. Penelitian Operasional: Teori Dan Praktek. Jakarta: UI Press.

[14] Pramuji, Bambang, Pitojo Tri Juwono, dan Widandi Soetopo. "Pemodelan Debit Menggunakan Metode Arima Guna Menentukan Pola Operasi Waduk
Selorejo.” Jurnal Teknik Pengairan, Volume 5, Nomor 2, Desember 2014, hlm 141-148.

[15] Prasetya, Hery, dan Fitri Lukiastuti. 2009. Manajemen Operasi. Yogyakarta: Media Pressindo.

[16] Rusdji, Darma. "Pembangkit Data Sekolah Secara Acak Menggunakan MSExcel.” JURNAL PETIR VOL. 4 NO 1 (2011).

[17] Sarjono, Haryadi, dan Engkos Achmad Kuncoro. "Analisis Perbandingan Perhitungan Re-order Point." BINUS BUSINESS REVIEW Vol. 5 No. 1 Mei 2014: 288-300.

[19] Suryani, E. (2006). Pemodelan dan Simulasi. Yogyakarta: Graha Ilmu.

[20] Trisnawati, Novi., Achmad Bahauddin, dan Ratna Ekawati. "Rancangan Perbaikan Pelayanan Puskesmas dengan Pendekatan Lean Healthcare dan Simulasi.” : ISSN 2302-495X: Jurnal Teknik Industri, Vol.1, No.1, Maret 2013, pp.71-76.

[21] Wahyono, Budi. 2012. Manajemen Persediaan (Inventory Management). [Online]. Tersedia: http://www.pendidikanekonomi.com/2012 /09/manajemen-persediaaninventory.html (diakses tanggal 26 Juni 2015). 